\title{
Draining the Flooded Markets: Tariffs, Suniva \& Solar Energy Investment
}

\author{
Michael A. Stroup \\ Indiana University Maurer School of Law, mistroup@indiana.edu
}

Follow this and additional works at: https://www.repository.law.indiana.edu/ijgls

Part of the Comparative and Foreign Law Commons, Energy and Utilities Law Commons, European Law Commons, Law and Economics Commons, and the Natural Resources Law Commons

\section{Recommended Citation}

Stroup, Michael A. (2019) "Draining the Flooded Markets: Tariffs, Suniva \& Solar Energy Investment," Indiana Journal of Global Legal Studies: Vol. 26 : Iss. 1 , Article 10.

Available at: https://www.repository.law.indiana.edu/ijgls/vol26/iss1/10

This Note is brought to you for free and open access by the Law School Journals at Digital Repository @ Maurer Law. It has been accepted for inclusion in Indiana Journal of Global Legal Studies by an authorized editor of Digital Repository @ Maurer Law. For more information, please contactrvaughan@indiana.edu.

\section{$\Psi$}

JEROME HALL LAW LIBRARY

INDIANA UNIVERSITY

Maurer School of Law
Bloomington 


\title{
Draining the Flooded Markets: Tariffs, Suniva \& Solar Energy Investment
}

\author{
MiCHAEL A. STROUP*
}

\begin{abstract}
Demand for solar energy in the United States has increased significantly over the past half century. Despite the falling costs of solar infrastructure, the United States solar energy market is at a turning point. In 2017, two insolvent U.S. solar manufacturers, Suniva and SolarWorld America, successfully petitioned the International Trade Commission (ITC) to invoke Section 201 of the 1974 Trade Act. The two U.S. manufacturers argued that a surplus of imported Chinese solar panels has driven the cost of solar infrastructure too low and forced them out of the market. The ITC responded by recommending tariffs on global solar photovoltaic (PV) panel imports, which were then implemented by President Trump in early 2018. This note addresses the negative effects that PV import tariffs have on investment in the U.S. solar energy market, posits that a free-market approach toward PV panel trade will maximize investment in solar energy, and explains that imposing tariffs on PV panel imports leads to more net harm than good.
\end{abstract}

\section{INTRODUCTION}

The generating capacity of renewable energy in the United States has grown at an astronomical rate since the beginning of the twentyfirst century. ${ }^{1}$ While the term renewable encompasses a myriad of

* Notes Editor, Indiana Journal of Global Legal Studies, Volume 26; J.D. Candidate, 2019, Indiana University Maurer School of Law-Bloomington; B.S., Economics, 2016, Eastern Michigan University-Ypsilanti. Many thanks to the Alternative Investment Division of Kyobo AXA Investment Managers Co., Ltd. for fueling my research in solar investments.

1. See U.S. EnERgy Information ADMinistration, DOE/EIA-0035 (2017/10), MONTHLY ENERGY REVIEW OCTOBER 2017, at 109 (2017).

Indiana Journal of Global Legal Studies Vol. 26 \#1 (Winter 2019)

(C) Indiana University Maurer School of Law 
energy sources, such as hydropower, biomass, and geothermal, ${ }^{2}$ the recent growth has come almost exclusively from wind- and solarpowered energy. ${ }^{3}$ Solar energy alone has grown in the United States from generating 493 million kilowatt-hours in 2000 to 36.75 billion kilowatt-hours in $2016^{4}$, a growth rate of over 7,000 percent.

The enormous growth in solar energy has mainly been driven by the declining production costs of photovoltaic (PV) panels worldwide. PV is defined as the conversion of light into electricity. ${ }^{5} \mathrm{PV}$ panels employ an array of individual PV cells that are made of a semiconductor material, most commonly silicon. ${ }^{6}$ When the energy from sunlight hits the PV cells, electricity is produced at the atomic level, which is then captured and redirected. ${ }^{7}$ This paper will not address concentrated thermal solar energy - a similar technology that converts sunlight into heat rather than electricity. Concentrated thermal solar energy is predominantly used for large-scale energy production by powering steam turbines. ${ }^{8}$

The global cost of producing energy from PV panels is nearly onequarter of what it was eight years ago ${ }^{9}$ and is projected to drop an additional 66 percent by $2040 .{ }^{10}$ Increased cost efficiency and installation rates leads to an influx of private and public investment into solar energy, which in turn drives production costs down further. In 2015 alone, $\$ 30.2$ billion were invested in the U.S. solar energy market. ${ }^{11}$

Through growing investments, the United States is attempting to bring solar energy onto the same playing field as fossil fuel energy sources. The investment outlook shifted, however, when Suniva, a U.S. PV panel manufacturer, filed for bankruptcy on April 17, 2017.12 Suniva was unable to compete with the declining PV costs driven by Asian

\footnotetext{
2. Id. at 230 .

3. See id. at 109 .

4. See id.

5. Gil Knier, How do Photovoltaics Work?, NASA (Aug. 6, 2008), https:/science. nasa.gov/science-news/science-at-nasa/2002/solarcells.

6. See id.

7. See id.

8. How Does Solar Work?, SOLAR ENERGY INDUS. ASS'N, https://www.seia.org/initiatives/how-does-solar-work (last visited Sept. 27, 2018).

9. Jess Shankleman \& Hayley Warren, Solar Power Will Kill Coal Faster than You Think, BLOOMBERG (June 15, 2017, 7:15 AM), https://www.bloomberg.com/news /articles/2017-06-15/solar-power-will-kill-coal-sooner-than-you-think.

10. BloOMberG New ENERGY FinANCE, NEw ENERGy OUTLOOK 2017, at 2 (2017).

11. See U.N. Env't Programme \& Bloomberg New Energy Finance, Global TRENDS IN RENEWABLE ENERGY INVESTMENT 2016, at 24 (2016).

12. Christian Roselund, Suniva Files for Chapter 11 Bankruptcy, PV MAG. (Apr. 18, 2017), https:/www.pv-magazine.com/2017/04/18/suniva-files-for-bankruptcy/.
} 
manufacturers, "which have flooded the U.S. with cheap panels." 13 Instead of accepting defeat, Suniva successfully petitioned the International Trade Commission (ITC) to invoke Section 201 of the 1974 Trade Act that "allows for temporary relief in situations where surging imports are causing "serious injury' to a U.S. industry." 14 SolarWorld America, a subsidiary of the German PV manufacturer, became a copetitioner weeks later when news broke of the company's insolvency. ${ }^{15}$ After conducting an investigation, the ITC determined that a serious injury existed ${ }^{16}$ and later recommended remedies including tariffs up to 35 percent and various annual quota caps on imported PV materials. ${ }^{17}$ In January 2018, President Trump opted to impose a four-year tariff schedule on all imported PV cells and panels, ranging from 30 percent in year one to 15 percent in year four. ${ }^{18}$

This note addresses the negative effects that PV import tariffs have on investment in the U.S. solar energy market, posits that a free-market approach toward PV panel trade will maximize investment in solar energy, and explains that imposing tariffs on PV panel imports leads to more net harm than good. Part I examines the history of investment in solar energy and explores the market expansion in recent decades. Part II assesses the relationship between tariffs and investment through a case study involving tariffs placed on Chinese PV imports in 2012 and 2014. Part III looks at the Suniva Section 201 case and weighs the reasons given in favor of tariffs on Asian PV imports against the effects on investment in the U.S. solar energy market through a fundamental economics lens.

13. Joe Ryan \& Jennifer A Dlouhy, This Case Could Upend America's \$29 Billion Solar Industry, BLOOMBERG (June 15, 2017), https:/www.bloomberg.com/news/articles/2017-0615/this-case-could-upend-america-s-29-billion-solar-industry.

14. Solar Section 201 Case - Frequently Asked Questions, SOLAR ENERGY INDUSTRIES Association, https://www.seia.org/initiatives/solar-section-201-case-frequently-askedquestions (last visited Oct. 27, 2017).

15. See Joe Ryan, SolarWorld Joins Case Seeking U.S. Duties on Cheap Solar Imports, BLOOMBERG (last updated May 26, 2017, 12:01 AM), https://www.bloomberg.com/news /articles/2017-05-25/solarworld-americas-joins-suniva-trade-case-for-import-duties.

16. Lacey Johnson \& Julia Pyper, Solar Tariff Case Advances as ITC Finds 'Tnjury', GREENTECH MEdia (Sept. 22, 2017), https:/www.greentechmedia.com/articles/read/solartrade-case-advances-as-itc-finds-injury.

17. See Julia Pyper, ITC Issues Recommended Remedies in Section 201 Solar Trade Case, GREEnTECH Media (Oct. 31, 2017), https://www.greentechmedia.com/articles /read/itc-solar-trade-case-recommendations.

18. Timothy Cama, Trump Imposes 30 Percent Tariff on Solar Panel Imports, THE HiLL (Jan. 22, 2018, 4:57 PM), http://thehill.com/policy/energy-environment/370171-trumpimposes-30-tariffs-on-solar-panel-imports. 


\section{RISE OF GLOBAL SOLAR INVESTMENT}

\section{Early Growth}

The first use of solar PV technology came in 1958 when it was used to power the radio system on the Vanguard I space satellite. ${ }^{19}$ The technology at that point, however, was nothing more than a luxury, considering the capital costs. Even a mere forty years ago, solar energy production on a mass-scale was unheard of. MIT's workshop on Alternative Energy Strategies reported in 1977 that "[e]ach year the world's solar energy income at ground level is about . . 1,000 times the energy of the known reserves of oil but efficient extraction of this abundant resource is difficult." ${ }^{20}$ Technology and cost-effectiveness simply was not present, but solar energy was not ruled out as a dominant force to come in the following decades. The same report added, "after the year 2000, solar can be expected to play an increasingly important role in the energy mix." 21

In hopes that solar energy would eventually play a prominent role in the not-too-distant future, a myriad of public and private investors began to pump large investments into the industry. It is said that the National Aeronautics and Space Administration (NASA) invested nearly $\$ 1$ billion in solar energy research and development (R\&D) between 1950 and 2006. ${ }^{22}$ Despite serious hurdles preventing solar energy growth by Washington conservatives and the fossil fuel industries in the 1980s, investment in the solar market continued to grow domestically and globally throughout the late twentieth century. ${ }^{23}$

\section{Private Investment Explosion}

At the turn of the century, investment in solar energy began to take off. The average cost of PV cells in 2000 was well below ten dollars

\footnotetext{
19. See U.S. Dep't of EnERGY, OfFICE of ENERgy EFFICIEncy AND Renewable ENERGy, THE History OF SOLAR 4 (last visited Oct. 27, 2017), https:/www1.eere.energy.gov/solar/pdfs/solar_timeline.pdf.

20. Workshop on Alternative Energy Strategies, Energy: Global Prospects 1985-2000, at 223 (1977).

21. Id. at 224 .

22. Nancy Pfund \& Ben Healey, What Would JefFerson Do? The Historical Role of Federal Subsidies in Shaping AMERICA'S EnERGy Future 18 (2011), http:/www.dblpartners.ve/wp-content/uploads/2012/09/What-Would-Jefferson-Do2.4.pdf?597435\&43c889

23. See Arthur Allen, Prodigal Sun, Mother Jones, Mar./Apr. 2000, http://www.motherjones.com/polities/2000/03/prodigal-sun/.
} 
per watt as compared to over seventy-six dollars per watt in $1977 . .^{24}$ Private investors saw the market was expanding through decreases in capital costs and realized the opportunity to make a profit. Global private capital investments in solar energy proceeded to grow from $\$ 66$ million in 2000 to $\$ 417$ million in $2003 .{ }^{25}$ Growth continued to expand exponentially to $\$ 2.5$ billion in $2005, \$ 7.1$ billion in 2006 , and $\$ 12.4$ billion in 2007. ${ }^{26}$ In the United States, public investment as a percentage of total investment shrank from an average of 50 percent between 2000 and 2004 to less than 4 percent in 2007, as private investment began to pour in. ${ }^{27}$

Between 2004 and 2007, global private equity dollars in the industry grew at an average annual rate of almost 300 percent to a sum of over $\$ 1.2$ billion in 2007.28 Venture capital also saw massive expansions, albeit more steady than private equity, and averaged annual growth at about 116 percent between 2004 and $2007 .{ }^{29}$

Not only is it important to see how much private investment has grown, but it is also equally important to see where it has gone throughout the world. In 2007, 57 percent of global private equity investment went to the European Union (EU), and a staggering 82 percent of global venture capital dollars went to the United States. ${ }^{30}$ This data paints a picture of the underlying regional policies. In the EU, several governments have been forthright and generous in subsidizing their nations' solar industries that in turn increases demand and attracts investment dollars to the expansion of existing infrastructure rather than emerging technology. ${ }^{31}$ In the United States-where public subsidies have been significantly smaller-private investment is more geared toward technology advancement, which attracts venture capitalists to the potential of future expansion.

While the global financial markets were in disarray following the collapse of the U.S. housing bubble in 2007 and 2008, the effects on the solar market were much smaller since private equity and venture

24. See Zachary Shahan, 13 Charts on Solar Panel Cost \& Growth Trends, CLEANTECHNICA (Sept. 4, 2014), https:/cleantechnica.com/2014/09/04/solar-panel-costtrends-10-charts/.

25. Charles E. Jennings et al., National Renewable Energy Laboratory, A HiSTORICAL ANALYSIS OF INVESTMENT IN SOLAR ENERGY TECHNOLOGIES (2000-2007), at 6 (2008)

26. Id.

27. See id. at 8 .

28. See id. at 11 .

29. See id.

30. Id.

31. See id. at 13 . 
capital tend to be "more insulated from financial shocks." 32 Surprisingly, global capacity for solar PV energy saw its strongest growth between 2008 and 2011 at an average annual rate of 75.25 percent. ${ }^{33}$ Despite a temporary global shortage of silicon-the main ingredient for PV cellscosts of solar PV production continued to fall, ${ }^{34}$ and solar energy played an increasingly prominent role in the aftermath of the crisis.

The solar industry continued its global expansion throughout the 2010 s as global regions outside of the United States, Europe, and Asia began utilizing solar energy on a large scale. ${ }^{35}$ In the United States, total investment in solar energy had grown to $\$ 29.3$ billion in $2016^{36}$ and contributed to the addition of over 115,000 domestic solar jobs between 2010 and 2015.37 However, venture capital and private equity investments in the U.S. solar market have dropped in recent years, ${ }^{38}$ perhaps showing that the domestic market is maturing as the European Union's market did a decade ago. As of 2016, the United States was ranked fifth in a list of countries that generate the greatest amount of solar energy. ${ }^{39}$ Germany was the global leader with more than double the generating capacity of the United States, and China and Japan took second and third, respectively. ${ }^{40}$

Bloomberg New Energy Finance projects that $\$ 2.8$ trillion will be invested in global solar energy by $2040 .{ }^{41}$ Additionally, research suggests that returns on renewable investments could reach an average of 10.1 percent over the next thirty-five years, ${ }^{42}$ but that is highly dependent on government policies: policies that can give a huge boost to

32. John E. Bartlett et al., NATiOnal Renewable ENERGy Laboratory, The EfFects of the Financial Crisis on Photovoltaics: AN ANALysis of Changes in MARKET FORECASTS FROM 2008 TO 2009, at 2 (2009).

33. See Office of Energy Efficiency \& Renewable Energy, 2015 Renewable ENERGY DATA BOOK 44 (2016).

34. See Leo Lewis, Silicon Shortage Hits Solar Power Hopes, THE FinANCIAL Times (Nov. 20, 2006), https:/www.ft.com/content/e50784ea-78cb-1 1db-8743-0000779e2340 (describing the silicon shortage and its effects); See also Shahan, supra note 24 (illustrating the long-term pricing trends of solar PV technology).

35. See KPMG, Global Trends in Renewable Energy 9 (2016).

36. U.N. Env't Programme \& Bloomberg New Energy Finance, Global Trends in RENEWABLE ENERGY INVESTMENT 2017, at 24 (2017).

37. The Solar Foundation, National Solar Jobs Census 2015, at 5 (2016).

38. See Ucilia Wang, The Ups and Downs of U.S. Solar Investments, FORBES (July 13, 2015, 5:42 PM), https:/www.forbes.com/sites/uciliawang/2015/07/13/report-the-ups-anddowns-of-u-s-solar-investments/\#6346f $3647 \mathrm{dfo}$.

39. Rebecca Harrington, These 10 Countries are Leading the World in Solar Energy, BUSINESS INSIDER (Mar. 15, 2016, 4:35 PM), http:/www.businessinsider.com/best-solarpower-countries-2016-3/\#6-france-5678-megawatts-5.

40. See id.

41. BLOOMBERG NeW ENERGY FINANCE, supra note 10 , at 2.

42. MerCer, Investing in A Time of Climate Change, at 15 (2015). 
solar energy investment and production or that leave the growing industry dead in the water.

\section{RELATIONSHIP BETWEEN SOLAR TARIFFS AND INVESTMENT}

Fool Me Once: 2012 Tariffs

On November 7, 2012, the ITC voted in favor of imposing tariffs on Chinese PV imports. ${ }^{43}$ The ITC found that "there is a causal nexus between subject [Chinese] imports and the poor condition of the domestic industry" and that such imports caused material injury to the United States solar market. ${ }^{44}$ As a result, Chinese PV cell manufacturers were forced to pay a tax up to 35 percent on exports to the United States. ${ }^{45}$ Gordon Brinser, president of the later bankrupt SolarWorld America, praised the decision: "Chinese manufacturers, with the enthusiastic support of the Chinese government, have attempted to game the international trading system in order to gain a virtual monopoly on solar cells and modules sales in the U.S. market." 46 Although the effects of the tariffs may not have lived up to the ITC's and Brinser's expectations, ${ }^{47}$ important lessons can be taken away from this decision.

To understand how these tariffs came into place, it is helpful to trace the history of China's involvement in the solar energy movement and how they became such a dominant player in this market. China joined the global solar energy movement in the 1990s when Germany persuaded it to develop a PV manufacturing base to meet German demand. ${ }^{48}$ At the time, Germany was pioneering solar power on a mass scale, and it needed to partner with a manufacturing giant such as

43. See Eric Wesoff, Final ITC Decision on SolarWorld's China-US Solar Trade Complaint, GREENTECH MEDIA (Nov. 7, 2012), https:/www.greentechmedia.com/articles /read/case-casm.

44. U.S. Int'l Trade Comm'n, Crystalline Silicon Photovoltaic Cells and MODULES FROM CHINA 30 (2011).

45. See Wesoff, supra note 43 .

46. Id.

47. See Megan Geuss, Chinese Solar Exports Fall in 2016 with Global Anti-Dumping Measures, ARS TECHNICA (Feb. 20, 2017, 7:12 PM) (statement of Zhang Sen, China's secretary general of the solar division) ("[D]espite the tariffs and duties, solar equipment from China is still prevalent throughout the world."), https:/arstechnica.com/informationtechnology/2017/02/chinese-solar-exports-fall-in-2016-with-global-anti-dumpingmeasures/.

48. See John Fialka, Why China is Dominating the Solar Industry, SCIENTIFIC AMERICAN (Dec. 19, 2016), https:/www.scientificamerican.com/article/why-china-isdominating-the-solar-industry/. 
China. ${ }^{49}$ According to Donald Chung, a solar energy researcher for the U.S. Department of Energy, "[t]he Chinese took [solar energy] and basically ran with it." ${ }^{50}$ It did not take long for Chinese manufacturers of PV panels to recognize the profits that could be made from solar expansion. China began to recruit some of the world's leading solar experts and companies to move to China by promising generous tax credits. ${ }^{51}$ Over the next two decades, China's solar manufacturing industry grew to dominate the global export market through cheap, skilled labor thereby "fundamentally chang[ing] the economics of solar all over the world." 52

By the early 2010s, the Chinese PV manufacturing industry had slashed the global cost of solar energy by 80 percent and became the main contributor to a worldwide PV surplus; "there were roughly two panels being made for every one being ordered by an overseas customer." 53 After seeing the global market flooded with Chinese PV panels, China shifted its focus inward by incentivizing the domestic generation of solar energy, which increased demand and fueled the manufacturing industry. ${ }^{54}$ As China's domestic solar market quickly grew, PV manufacturers elsewhere in the world began filing for bankruptcy; ${ }^{55}$ many pointed the finger at the Asian powerhouse for driving prices below their bottom line. ${ }^{56}$

The massive growth of China's solar manufacturing industry culminated with the United States' announcement of tariffs on Chinese PV imports. The announcement ignited widespread backlash by solar energy advocates within the United States and abroad. Proponents of free trade claimed that imposing these tariffs would significantly increase the cost of PV generation and dry up global demand, both of which would have dire effects on investment. ${ }^{57}$ However, to the surprise of many, a steady flow of Chinese PV panels continued to reach the United States' market despite the tariffs. This was not because PV

49. See id.

50. Id.

51. See id.

52. Id.

53. Id.

54. See id

55. See Eric Wesoff, Rest in Peace: The List of Deceased Solar Companies, GREENTECH MEdiA (Apr. 6, 2013), https://www.greentechmedia.com/articles/read/Rest-in-Peace-TheList-of-Deceased-Solar-Companies.

56. See Jeffrey Ball, The Next Battle in Our Trade War with China, New REPUBLIC (Jan. 21, 2014), https://newrepublic.com/article/116286/solar-panel-trade-war-china.

57. See Nick Stockton, Why the U.S. Solar Industry Doesn't Want Government Protection, WIRED (Aug. 21, 2017, 11:00 AM), https://www.wired.com/story/why-the-ussolar-industry-doesnt-want-government-protection/. 
exporters chose to pay the added fees to continue shipping panels into the United States but rather because the exporters found a loophole in the tariff order. ${ }^{58}$ The loophole allowed PV panels to be imported tarifffree if they were built outside of China regardless of where they were later assembled. ${ }^{59}$ As a result, Chinese PV manufacturers outsourced manufacturing jobs to other Asian nations - most notably Taiwan - and shipped the manufactured materials back to China where they would be assembled and exported to the United States at no extra cost. 60

China also retaliated by imposing tariffs of its own on U.S. exports of polysilicon, the main ingredient used in PV cells to generate energy. ${ }^{61}$ U.S. polysilicon manufacturers accounted for around 24 percent of the global supply in 2012, much of which was sold to Chinese PV manufacturers. ${ }^{62}$ The tariffs, set at 57 percent, effectively made it impossible for U.S. polysilicon manufacturers to sell their products to Chinese buyers. ${ }^{63}$ As a result, manufacturers were forced to halt plans for expansion and, in some instances, shut down existing manufacturing facilities. ${ }^{64}$ The polysilicon tariffs still exist today.

While Chinese PV panels continued flowing into the United States after the 2012 tariffs, investment in U.S. solar energy took a major blow. Solar investment in the United States totaled $\$ 27.6$ billion in $2011^{65}$ but fell to $\$ 8.8$ billion in 2012.66 The decline cannot be attributed entirely to the tariffs, ${ }^{67}$ but surely the tariffs imposed by both nations played a role in deteriorating market confidence that ultimately led to over two-thirds of total investments being pulled from the market. Simply, the tariffs did not amount to the positive effects on the domestic

58. See Ball, supra note 56.

59. See id.

60. See id.

61. Steven Mufson, Chinese Tariffs May Hurt U.S. Makers of Solar Cells' Raw Material, WASH. POST (July 23, 2013), https:/www.washingtonpost.com/business/economy /chinese-tariffs-may-hurt-us-makers-of-solar-cells-raw-material/2013/07/23/01ac60a4-f3d9-

11e2-aa2e-4088616498b4_story.html.

62. See id.

63. See Willian Pentland, China Scores Big Win in Solar Trade Battle as REC Silicon Shutters US Polysilicon Production, ForBes (Feb. 8, 2016, 8:50 AM), https:/www forbes.com/sites/williampentland/2016/02/08/china-scores-big-win-in-solartrade-battle-as-rec-silicon-shutters-us-polysilicon-production/\#422c7efd269d.

64. See, e.g., Mark Osborne, REC Silicon Stopping all FBR Polysilicon Production at Moses Lake Plant, PV-TECH (Feb. 8, 2016), https:/www.pv-tech.org/news/rec-siliconstopping-all-fbr-polysilicon-production-at-moses-lake-plant.

65. U.N. ENv'T Programme \& BlOOMBERG NEW EnERGy FinanCe, Global Trends in RENEWABLE ENERGY INVESTMENT 2012, at 25 (2012).

66. U.N. Env't Programme \& BloomberG New EnERGy Finance, Global Trends in RENEWABLE ENERGY INVESTMENT 2013, at 24 (2013).

67. See $i d$. (noting that expiration of federal tax and loan incentives played a role in the investment decline). 
manufacturing sector that advocates had hoped. Arguably, the tariffs did more harm than good by forcing many domestic polysilicon and PV panel manufacturers to scale back rather than expand outward.

\section{Fool Me Twice: 2014 Tariffs}

After being outsmarted by the vast Asian PV manufacturing industry, the United States proposed a second round of tariffs on Chinese PV materials in December 2014.68 The primary goal of the new tariffs was to close the loophole that had allowed China to entirely sidestep the earlier tariffs by including PV materials manufactured in Taiwan to the tariff import list. 69

As in 2012, there was a clear dichotomy between those in favor of tariffs and those opposed. SolarWorld America, albeit under the new president, Mukesh Dulani, spoke in high praises of import taxes and claimed that "[t]he tariffs . . set the stage for companies to create new jobs and build or expand factories on U.S. soil." 70 On the other side, the president of the Coalition for Affordable Solar Energy attested, "[t]hese unnecessary taxes inhibit competition and put upward pressure on solar panel prices needed by U.S. homeowners, installers and utilities."71 Slate news even went so far as to describe the escalating conflict with China as "[t]he world's dumbest trade war." 72

In an unsurprising repeat of the 2012 tariff aftermath, the U.S. solar market lacked significant change following the implementation of the 2014 tariffs. The cost of PV panels did not increase as tariff advocates had hoped but rather continued to fall to record lows. ${ }^{73}$ Similarly, there was not a drop in Asian PV imports. In fact, export production of PV equipment from other Asian nations, such as Malaysia, ${ }^{74}$ Vietnam, and Thailand skyrocketed. ${ }^{75}$ In 2016 , the United

68. See Diane Cardwell, U.S. Imposes Steep Tariffs on Chinese Solar Panels, N.Y. TimES (Dec. 16, 2014), https://www.nytimes.com/2014/12/17/business/energy-environment /-us-imposes-steep-tariffs-on-chinese-solar-panels.html.

69. See id.

70. $I d$

71. Id.

72. Will Oremus, The World's Dumbest Trade War, SLATE (Feb. 19, 2014, 10:13 AM), http://www.slate.com/articles/technology/technology/2014/02/us_china_solar_trade_war_so larworld_case_is_bad_for_green_jobs.html

73. See Eric Wesoff \& Stephen Lacey, Solar Costs are Hitting Jaw-Dropping Lows in Every Region of the World, GREENTECH MediA (June 27, 2017), https:// www.greentechmedia.com/articles/read/solar-costs-are-hitting-jaw-dropping-lows-in-everyregion-of-the-world.

74. See Keith Bradsher, Solar Rises in Malaysia During Trade Wars over Panels, N.Y. Times (Dec. 11, 2014), https://www.nytimes.com/2014/12/12/business/energy-environment /solar-rises-in-malaysia-during-trade-wars-over-panels.html. 
States imported $\$ 520$ million in PV panels from Thailand and $\$ 514$ million from Vietnam, both of which accounted for less than $\$ 1$ million in imports four years earlier. ${ }^{76}$ China had simply found another loophole; since it could not export from its own soil any longer, it moved manufacturing and assembly operations to other Asian nations that could export PV panels freely. ${ }^{77}$

Meanwhile, investment in the U.S. solar market has steadily recovered from its significant decline after the first set of tariffs. In 2015 , total investment in U.S. solar energy reached over $\$ 30$ billion, which surpassed 2011 totals. ${ }^{78}$ The surge has largely been led by investments through public markets, and many PV manufacturers have been forced to raise capital through IPOs and secondary offerings to remain afloat. ${ }^{79}$ There has also been a swell in solar investment by U.S. utility companies who wish to capitalize on the low costs of PV panels and prepare for increased future demand. ${ }^{80}$ The 2014 tariffs did not shock the market as the earlier tariffs did likely because investors have relied on the assumption that Chinese PV manufacturers will continue moving operations internationally. As long as China can move its manufacturing across borders to avoid tariffs, PV costs can be expected to remain low, and China can maintain installation demand.

Clearly, both attempts to suppress low-cost PV imports through tariffs have resulted in an overwhelming failure. Today, PV costs are lower than ever, ${ }^{81}$ and both the United States and China have suffered countless bankruptcies among their domestic solar industries because of the trade war between them. ${ }^{82}$ The U.S. solar market remains flooded with foreign PV panels, and investment in the market has bounced back to pre-tariff levels. However, given the new set of PV tariffs imposed by President Trump in 2018, the question becomes whether costs of PV

75. See Finlay Colville, Thailand and Vietnam Become Lead Countries for OEM Solar Module Supply, PV-TECH (Feb. 3, 2017, 11:15 AM), https:/www.pv-tech.org/editorsblog/thailand-and-vietnam-become-lead-countries-for-oem-solar-module-supply.

76. See Marc Gunther, Could a Trade Dispute with China Bring an End to U.S. Solar Boom?, YALE ENVIRONMENT360 (June 27, 2017), https:/e360.yale edu/features/couldtrade-dispute-with-china-bring-an-end-to-u-s-solar-boom.

77. See id

78. See U.N. Env't Programme \& BloOmberg New EnERGy FinanCe, supra note 11, at 24 .

79. U.N. Env't Programme \& Bloomberg New Energy Finance, Global Trends in RENEWABLE ENERGY INVESTMENT 2015, at 64 (2015).

80. Robert Ferris, US Solar Installations Nearly Doubled in 2016, and Broke some Records, CNBC (Feb. 15, 2017, 10:51 AM), https://www.cnbc.com/2017/02/14/us-solarinstallations-nearly-doubled-in-2016-and-broke-some-records.html.

81. Ran Fu et al., Nat'L Renewable Energy Lab., U.S. Solar Photovoltaic System COST BENCHMARK: Q1 2017, at vi (2017).

82. See Wesoff, supra note 55 . 
manufacturing can continue to fall-and whether investment in the market can ever recover-under such isolationist trade policies.

\section{WHY IMPOSING PV TARIFFS IS A BAD IDEA}

While working in Seoul shortly after Suniva successfully petitioned the ITC to initiate the Section 201 case on Asian PV imports, I attended a seminar titled What to Expect from the U.S. Energy Market in 2017. Hundreds of Korean investors filled a conference hall and listened to experts from Bloomberg, Wells Fargo, Clifford Chance, and other institutions discuss various aspects of the U.S. energy market. When time was allotted for an audience response, I noticed a reoccurring theme among questions being asked; several audience members were curious about the effects of the recent news by the ITC regarding Suniva. I could feel their distraught attitudes about what tariffs could mean for their solar investments. They were scared and, although for different reasons, I was scared too.

\section{Adding Suniva to the Mix}

When Suniva announced that it was filing for Chapter 11 bankruptcy in April 2017, there was little surprise among those who had previously followed the U.S. solar energy markets. The manufacturer had been announcing for weeks that it would be making significant layoffs and that it was struggling to compete with low production costs. ${ }^{83}$ It was equally unsurprising when SolarWorld America announced its insolvency just weeks later ${ }^{84}$ and joined forces with Suniva to call for the very same remedy that proved ineffective twice before: more tariffs. ${ }^{85}$ After all, SolarWorld had been the vocal leader of the push for tariffs on PV imports in both 2012 and 2014. ${ }^{86}$ This time, however, they wanted to go a step further and impose tariffs globally. Matthew McConkey, Suniva's attorney, stated, "Without global relief, the domestic industry will be playing 'whack-a-mole' against . . . modules from particular countries." 87

Section 201 of the 1974 Trade Act had not been successfully invoked

\footnotetext{
83. See Heather Jordan, Suniva Reports 59 Layoffs to State of Michigan, MLIVE (Apr. 4, 2017), http://www.mlive.com/news/saginaw/index.ssf/2017/04/future_of_sunivas_ saginaw_coun.html.

84. See Jonathan Gifford, Breaking: SolarWorld Insolvent, PV MAGAZINE (May 10,

2017), https:/www.pv-magazine.com/2017/05/10/breaking-solarworld-insolvent/.

85. See Ryan, supra note 15.

86. See Cardwell, supra note 68 ; see also Wesoff, supra note 43.

87. Gunther, supra note 77.
} 
since 2002 when the domestic steel industry persuaded the ITC and President Bush to impose tariffs on certain steel imports. ${ }^{88}$ The nation was as divided then on the issue of steel tariffs as it is now with solar energy tariffs. However, the steel tariffs only existed for a year before they were reversed by the president for failure to comply with international law. ${ }^{89}$ Although the short-lived steel tariffs were declared a victory by the Bush administration, steel production in the United States fell nearly 7 percent during the life of the tariffs. ${ }^{90}$ The effectiveness of Section 201 in safeguarding and promoting domestic industry has been questioned by many as empirical evidence has shown that its positive effects are little to none when compared to its costs. ${ }^{91}$

Although Suniva and SolarWorld America successfully persuaded the ITC to recommend tariffs, the proposed tariffs by the four ITC commissioners were less severe than the two manufacturers' proposals. Both petitioned for tariffs of twenty-five cents per watt on PV cells and thirty-two cents per watt on assembled PV panels. ${ }^{92}$ However, the two proposals differed in that Suniva sought a price floor on all imported solar products, while SolarWorld America proposed a quota system that would cap imports of both cells and panels. ${ }^{93}$ Both manufacturers came to the negotiating table with their strongest hand.

The four ITC commissioners concluded their investigation by announcing three separate tariff proposals, all of which excluded certain free-trade agreement partners. ${ }^{94}$ The first proposal, agreed on by two commissioners, would impose a four-year, one gigawatt quota cap on PV products, with a tariff of 30 percent on PV products exceeding the quota. The proposed quota would increase by 0.2 gigawatts annually, and the tariff would decrease by 5 percent annually over the life of the program. ${ }^{95}$ The proposals set forth by the other two ITC commissioners fell on opposite ends of the spectrum: one imposing a more severe quota of 0.5 gigawatts and one with a much more import-friendly quota of 8.9

88. See Eliza Patterson, The US Provides Section 201 Relief for the American Steel Industry, AM. SOC'Y OF INT'L LAW (Mar. 19, 2002), https:/www.asil.org/insights/volume/7 /issue/4/us-provides-section-201-relief-american-steel-industry.

89. See Dan Ackman, Bush Cuts Steel Tariffs, Declares Victory, ForBES (Dec. 5, 2003, 8:59 AM), https://www.forbes.com/2003/12/05/cx_da_1205topnews.html\#21cea1df2ab1.

90. See id.

91. See David Ryan, The Effects of Section 201 Safeguards on U.S. Industries, 44 GEO.

J. INT'L L. 249, 253 (2012).

92. Pyper, supra note 17.

93. See id.

94. See id. (excluding nations such as Australia, Israel, Singapore, and several Latin American nations).

95. See id 
gigawatts. ${ }^{96}$ Ultimately, President Trump imposed a four-year tariff schedule most similar to the ITC's first proposal. ${ }^{97}$ Under Trump's program, the quota is set at 2.5 gigawatts, and the tariff will decrease from 30 percent to 15 percent over the life of the program. 98

Since Suniva and SolarWorld America invoked the Section 201 trade case, cries in opposition of tariffs once again echoed throughout the U.S. solar market. The earlier tariffs proved to be bearable because of their limited scope that only required Chinese manufacturers to jump around from nation-to-nation in Southeast Asia, but global tariffs now mean that the manufacturers are forced to operate within the United States to competitively sell PV materials in the U.S. solar market. Domestic PV costs have continued to fall despite the 2012 and 2014 tariffs, but surely this trend will not continue now that the United States has effectively isolated itself from the global markets.

\section{Can Global Tariffs Result in Positive Benefits?}

Among the U.S. population, there is a clear contrast between those in favor of PV tariffs as imposed by President Trump and those opposed. Advocates cite domestic job growth in solar manufacturing and incentives for product innovation through higher costs as positive benefits that will result from imposing further tariffs. Although these are valid considerations, adopting a free-market trade approach can achieve both job growth and innovation while keeping solar costs low.

\section{Job Growth?}

Jobs are important, and in a competitive, globalized world, it is vital to promote and support a domestic workforce. Rightfully, advocates of PV tariffs are worried that all solar jobs will be lost overseas if costs are not inflated to preserve the domestic solar industry. However, this argument overlooks the fact that not all solar energy jobs are in manufacturing. The United States is a very small player in global PV manufacturing. Only about 1 percent of global PV cells and panels were manufactured in the United States in 2015. ${ }^{99}$

There is a plethora of jobs outside of manufacturing in the solar industry, such as installation, maintenance, sales, and R\&D. These are best suited for a domestic workforce and increase as the solar market

96. See id.

97. See Cama, supra note 18.

98. Id.

99. Jeffrey Ball et al., Stanford Univ., Steyer-Taylor Ctr. for Energy Policy and FinanCe, The New SOlar System 166 (2017). 
expands. Instead of focusing solely on manufacturing, the United States should be creating utility "throughout the product lifecycle," thereby "making value" as opposed to "making things." 100 This is underscored by the fact that the 2012 and 2014 tariffs had little to no effect on U.S. PV manufacturing but seriously affected the domestic polysilicon manufacturing industry, which fell from about 25 percent in 2012 to only 10.6 percent of the global supply in 2015 . The escalating trade war with China and other Asian PV manufacturers has proven costly, and by digging a deeper hole with more tariffs, the United States is losing sight of the possibilities that exist on the remainder of the product lifecycle spectrum.

The United States cannot efficiently compete with its Asian competitors in the manufacturing realm due to wage gaps, and even if tariffs can level the competition, most manufacturing jobs will be filled by robotics in the near future. Rather than focusing on the lost cause of a prominent solar manufacturing industry, the United States should focus on keeping PV costs low to promote job growth in other areas of the solar lifecycle.

\section{Innovation Incentives?}

Among those in favor of tariffs on PV panels, a recurring phrase is green mercantilism. According to the Information Technology \& Innovation Foundation green mercantilism is defined as:

[T]he adoption of policies that give countries an unfair advantage to boost exports and limit imports of clean energy technologies . . . a major departure from rulesbased clean technology trade. It's represented by "beggar-thy-neighbor" policies, including lax IP enforcement, forced technology transfer, export subsidies, discriminatory standards, barriers to imports, and preferential treatment of domestic firms by their parent governments. ${ }^{101}$

Tariff advocates claim that China stifled PV manufacturing and innovation through green mercantilist policies. ${ }^{102}$ Considering a small

100. NAt'L ACAD. OF ENG'G, Making Value FOR America 14 (Nicholas M. Donofrio \& Kate S. Whitefoot, eds. 2015).

101. Matthew Stepp \& Robert D. Atkinson, The Info. Tech. \& Innovation Found, Green Mercantilism: Threat to the Clean EnERGy ECONOMY 1 (2012).

102. See August Rick, The U.S. and China's Battle over Solar May Actually Benefit the Industry Worldwide, FORBES (Jan. 18, 2018, 1:00 PM), https://www.forbes.com/sites/ 
number of manufacturers encompass a clear majority of Chinese PV panel production, there are few incentives for them to innovate, ${ }^{103}$ and costs are too low to incentivize innovation elsewhere. However, the same advocates fail to consider that the United States now plays just as great of a role in green mercantilist policymaking by imposing tariffs as China has in the past decade by flooding the global markets with its manufactured PV panels.

Further, advocates complain about the Chinese government giving subsidies to PV manufacturers, which allows them to operate at a lower bottom line. Again, advocates fail to consider that the United States has been doing the same thing for years, notably the state of Michigan, which provides Suniva with favorable tax incentives to build its factory in Saginaw. ${ }^{104}$ The subsidies given by the federal and state governments in the United States may not be as generous as those provided by the Chinese government, but the fact remains that China and the United States are not so different when it comes to solar policymaking.

This is not to say that green mercantilism does not have any negative effects. Such protectionist policies significantly impact innovation, which in turn impacts investment. ${ }^{105}$ However, advocates of PV tariffs may be misguided in their emphasis on innovation. While innovation is important, it should be viewed as a result of a thriving solar market rather than the means to achieve such a market. Emphasis should instead be placed on keeping costs of solar energy as low as efficiently possible. With low costs in place, the U.S. solar market will have the ability to expand and thrive through increased demand, which will produce more jobs in non-manufacturing roles. As the domestic market expands, innovation will follow by way of increased market capital.

\section{Using Economics to Challenge Tariff Theory}

As I have shown, increasing costs of solar PV production through tariffs will not galvanize the domestic solar manufacturing industry; rather, it will restrain the growth of the solar markets. By looking at the situation through an economic lens, the law of demand states that as prices fall, demand increases. Conversely, when prices rise, fewer consumers will find it efficient to purchase any given product. If demand in any market dries up, producers are forced to either cut costs and

\footnotetext{
augustrick/2018/01/18/why-a-solar-tariff-in-the-u-s-could-benefit-othercountries/\#3711a7815c8b.

103. See Gunther, supra note 77.

104. See id.

105. See STEPP \& ATKINSON, supra note 101, at 3 .
} 
scale down or exit the market. The reduced supply as a result will drive prices up further. The solar market is not any different. If solar production costs are increased by imposing tariffs on cheaper materials, demand in the United States for solar energy will fall, and the domestic market will shrink. In some markets, consolidation can be a good thing, but the market for a public good such as solar energy should remain diverse to keep prices low and demand high.

When market growth is restrained, so too is investment. One of the foundational principles of economies is comparative advantage. Comparative advantage posits that total output and consumption can be increased through trade, such that "every country . . . would benefit from specializing in what it was relatively best at producing and then engaging in trade for everything else." 106 Clearly, China has a comparative advantage over the United States in PV manufacturing, as shown by China's ability to scale up manufacturing infrastructure and dominate the global market in a relatively short period of time. Likewise, the United States arguably has a comparative advantage over China in solar R\&D, as shown by the United States' track record in delivering cutting-edge advancements in solar technology. ${ }^{107}$ Rather than economically isolating one's self through tariffs, the United States and China could increase global investment in solar energy by specializing in R\&D and manufacturing, respectively, and trading freely with the other.

To ensure economic gain and to maximize investment in the solar market, the United States needs to "help maximize the industry's efficient global growth." 108 There is certainly a circular relationship between production, market expansion, costs, and investment. Investment leads to expansion in the market, which leads to increased production and, eventually, to lower costs. Lower costs lead to greater demand and greater investment to meet such demand. Each element relies on the others. Tariffs, on the other hand, break the chain by increasing costs, thereby impeding efficient global growth.

Instead of focusing on expanding an inefficient domestic PV manufacturing industry, the United States should be opening itself up for trade with the rest of the world to capitalize on the increasingly globalized nature of the solar energy industry. Investments in the solar market extend across national borders, often intertwining the markets of two or more nations. Investments in Chinese PV manufacturing rely on investments in U.S. R\&D, and vice versa. Output expands at an

106. David A. Moss, A Concise Guide to MaCroeConomics 16 (2007).

107. See BALL ET AL., supra note 99, at 167-68 (explaining that the United States is among the global leaders in solar R\&D).

108. Id. at 162 . 
efficient rate when nations specialize and cooperate with each other, and investment benefits as a result. While it may be tempting to isolate and promote domestic manufacturing, the costs associated with such a strategy are far outweighed by the benefits of free trade.

\section{CONCLUSION}

Solar energy has made enormous strides in the past half-century, but it faces significant hurdles-namely, the need for further investment - if it is to assume a significant proportion of total energy generated in the United States. The United States is at a turning point in which it has chosen to isolate itself from global PV manufacturing rather than embracing the fact that "making value" does not always equate to "making things." Imposing tariffs on PV cells and panels has been a losing battle for the United States over the past five years, and it is time to recognize that expanding tariffs will lead to more harm than gain. For investment to flourish, the United States needs to take a new position going forward by placing an emphasis on cutting PV costs and embracing the comparative advantages of its global competitors through free-market policies. As prices fall, output will expand, and investment will follow. The solar industry has accomplished more in the past fifty years than was ever previously thought possible. There is no reason why its incredible growth should stop now. 